\title{
Changes of Landscape Spatial Structure as a Result of Transformation of Land-Ownership
}

\author{
Margarita Jankauskaité ${ }^{1}$, Darijus Veteikis ${ }^{2}$ \\ 1 - Nature Research Centre Institute of Geology and Geography, T. Ševčenkos str. 13, LT-03223, \\ Vilnius \\ 2 - Vilnius university, Faculty of Natural Sciences, M. K. Čiurlionio str. 21/27, LT-03101, Vilnius
}

\begin{abstract}
The aim of the research is to analyse the landscape structure changes from the end of the Soviet times in 19741986 until 2005 when market economy existed in Lithuania. The changes of landscape structure were observed in 100 sample areas (squares) each of them having $2.5 \mathbf{~ k m}^{2}$ area and distributed in different landscape types. The changes in sample areas (squares) with determination of land cover structure transformations were observed using topographic photos and ortophoto images at a scale 1:10 000. More distinct manifestation of landscape re-naturalisation through land abandonment and conversion to forests, swamps and shrubs, also through transformation of arable land to meadows and pastures was the main direction of land cover changes. The opposite but lower scale conversion of forests, shrubs and other land use types to agrarian fields was also noticed. Acceleration of the conversion of landscape structure towards technogenisation through quick expansion of construction, recreational use and development of infrastructure was another important landscape structure conversion going on in the opposite direction of technogenisation. It manifested mainly as the change of agrarian fields, suburban gardens to built-up territories and as increase of percentage of other land use types related to them (ponds, streets and roads).
\end{abstract}

Keywords - deforestation, land cover structure, land use, spontaneouos forestation.

\section{INTRODUCTION}

Development of Lithuanian landscape is very dynamic with periods of evolution and sudden changes. It is related to the changes of social, economical, political conditions, of abundant socio-economical reforms which left their mark in present landscape structure. Current Lithuanian landscape contains reflections of various past socialeconomic reforms recorded in landscape mosaics and land use structure. Especially sudden, as seen from our modern perspective, are the landscape structure changes that have taken place in Lithuania after regaining the Independence and after approving certain programmes of land restitution. The latter stimulated the fragmentation of owned land, bringing our country somewhat back to the interwar period, only with the traces of Soviet land management and signs of some new elements in our landscape.

Observation of landscape state in Lithuania has been done since 1999 as State monitoring [1]. However, the transformations observed by analyzing CORINE Land Cover which is intended to track the changes of large areas (scale 1:100 000) do not allow to reveal detailed fragmentation of landscape which is especially specific to such landscape types as lake areas, river valleys, morainic hills. The analysis of landscape structure changes in a more detailed scale (1:10 000) proposed by us enables to reveal not only the small changes of landscape mosaic, but also the changes of linear or point objects. The knowledge about them is especially important for purposeful forming of the directions of state landscape protection and management, for preparing of documents of different level territorial planning and for organising the activity for landscape forming and restoration.

\section{METHODS}

The methodology of observation of landscape changes was described in detail during preparation of landscape monitoring program in previous article of the authors [2].

The changes of landscape were estimated in 100 sample areas each having $2.5 \mathrm{~km}^{2}$ area (the length of the sides being $1581 \mathrm{~m}$ ) which were distinguished in the main landscape types of Lithuania (Fig. 1) when analysing cartographic material at the scale 1:10000 (Soviet time aerial photographs of 1974-1986 and orto-photo views of 2005-2006) with the help of Arc/View 9.3 software. Thirty two land cover types were distinguished and their changes were observed during the above-mentioned period in each sample area. The statistical regularities of their distribution were determined for the whole territory of Lithuania. About 9000 plots with changes were distinguished which in total cover more than 4000 ha area.

The changes of land cover categories and the level of fragmentation were calculated and the main directions of landscape conversion were revealed. More detailed principle of evaluation of landscape structure changes has been discussed by the authors in another article [3].

\section{RESULTS AND DISCUSSION}

After regaining the Independence, the fragmented small-scale land-ownership and land use structure was formed in Lithuania. Therefore it is normal that most of the changes are small: the average area of plot with 
changes is about 0.5 ha and plots less than 0.5 ha area comprise almost $80 \%$ of total number of plots with changes (Table 1). Especially small changes are observed in landscape types with the greatest fragmentation: lake areas, river valleys, morain hills.

Total changes of land cover in distinguished sample areas during the study period comprise even $17.4 \%$ indicating great transformations of landscape in Lithuania. It should be noted that the fragmentation of land cover significantly increased during the study period (Table 2). This fact is proven by the marked increase of the number of land use type units in the study territory (from 3127 to 4813 ) and by the respective decrease of the average area of land use plot (from 8 to $5.5 \mathrm{ha}$ ). The growth of landscape fragmentation is especially remarkable due to the increase of the shrubby areas and swamps both in the forested territories and in the agrarian fields, as well as due to growing extent of cuttings in the forested territories. The process of spontaneous forestation (conversion of arable land to shrubby meadows) is a characteristic phenomenon at the beginning of the period of the Independence it is manifested in the whole country, especially in those areas where according to other authors [4, 5] agriculture is weak due to poor soils.

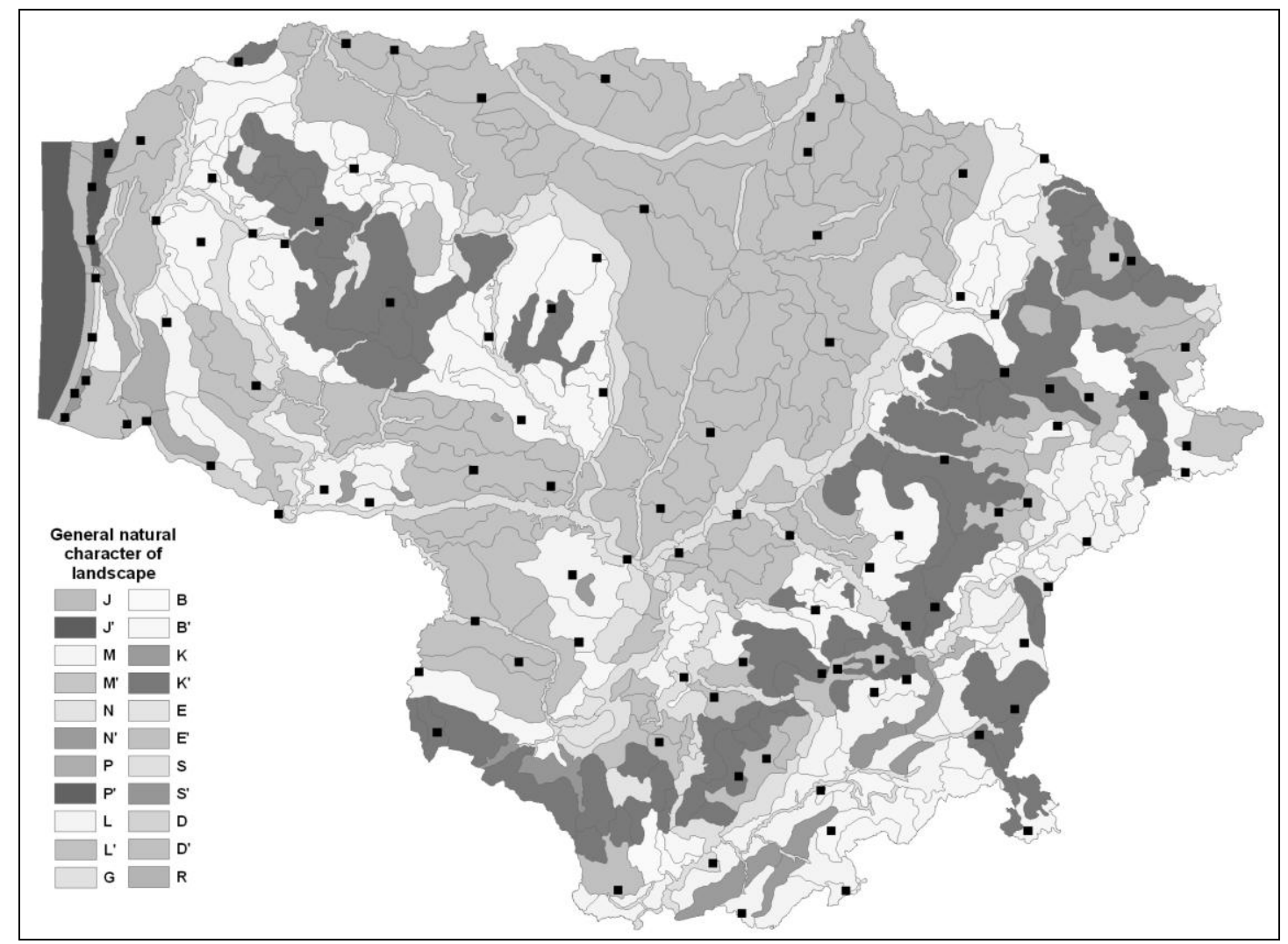

Fig. 1. Landscape sample areas (black squares) in different natural landscape types of Lithuania (map according to [6]

Natural character types of landscape: $\mathbf{J}$ - marine landscape in the coastal zone (at a depth of $<20 \mathrm{~m}$ ); $\mathrm{J}^{\star}-$ underwater plateaus and troughs; $\mathrm{M}$ shallow lagoon (at a depth of $<2 \mathrm{~m}$ ); $\mathrm{M}^{\triangleleft}$ - deep lagoon; $\mathrm{N}$ - smoothened spit; $\mathrm{N}^{\star}$ - rugged spit; $\mathrm{P}$ - lagoon coastal plain; $\mathrm{P}^{\star}-$ sandy coastal plain; $\mathrm{L}$ continental sandy plains; $\mathrm{L}^{`}$ - clayey plains; $\mathrm{B}$ - sandy downy plateaus; B` - clayey downy plateaus; $\mathrm{G}$ - morainic hills; $\mathrm{K}$ - sandy hills; $\mathrm{K}^{\text {‘ }}$ morainic hills; E - troughs with lakes; $\mathrm{E}^{`}$ - lake terrains; $\mathrm{S}$ - valleys; $\mathrm{S}^{`}$ - old valleys; $\mathrm{D}$ - delta valley; $\mathrm{D}^{`}$ - delta; $\quad \mathrm{R}$ - erosion washes.

TABLE 1.

STRUCTURE OF CHANGES ACCORDING TO THE SIZE OF AREAS

\begin{tabular}{|l|l|l|l|l|}
\hline $\begin{array}{l}\text { Area (ha) of plots with } \\
\text { changes }\end{array}$ & $\begin{array}{l}\text { Number of plots with } \\
\text { changes }\end{array}$ & \% from total number & $\begin{array}{l}\text { Area (ha) of plots with } \\
\text { changes }\end{array}$ & \% from total area \\
\hline less than 0.1 ha & 3933 & 45.2 & 129.8 & 3.0 \\
\hline from 0.1 to 0.5 ha & 2975 & 34.2 & 717.1 & 16.5 \\
\hline from 0.5 to 1 ha & 813 & 9.3 & 570.5 & 13.1 \\
\hline from 1 to 5 ha & 870 & 10.0 & 1798.8 & 41.3 \\
\hline from 5 to 10 ha & 71 & 0.8 & 502.3 & 11.5 \\
\hline more than 10 ha & 40 & 0.5 & 634.9 & 14.6 \\
\hline Total & 8702 & 100.0 & 4353.3 & 100.0 \\
\hline
\end{tabular}


TABLE 2.

CHANGES OF LAND COVER CATEGORIES.

1 - AT THE END OF THE SOVIET TIME (ACCORDING TO AERIAL PHOTOGRAPHS). 2 - IN 2005-2006 (ACCORDING TO ORTO-PHOTO VIEWS).

\begin{tabular}{|c|c|c|c|c|c|c|c|c|c|}
\hline \multirow[t]{2}{*}{ Land cover type (category)) } & \multicolumn{3}{|c|}{ Number of land use units } & \multicolumn{3}{|c|}{ Area (ha) of land use type } & \multicolumn{3}{|c|}{$\%$ from total area } \\
\hline & 1 & 2 & Change & 1 & 2 & Change & 1 & 2 & Change \\
\hline Forests. swamps and schrubs & 1340 & 2094 & 754 & 8196.6 & 9110.7 & 914.2 & 32.79 & 36.45 & 3.66 \\
\hline Forests & 856 & 1001 & 145 & 7138.6 & 7441.6 & 303.0 & 28.56 & 29.77 & 1.21 \\
\hline Young forests & 216 & 246 & 30 & 564.9 & 760.7 & 195.8 & 2.26 & 3.04 & 0.78 \\
\hline Forest cuttings & 12 & 127 & 115 & 36.7 & 259.4 & 222.6 & 0.15 & 1.04 & 0.89 \\
\hline Schrubs & 175 & 535 & 360 & 150.9 & 365.8 & 214.9 & 0.60 & 1.46 & 0.86 \\
\hline Swamps & 81 & 185 & 104 & 305.5 & 283.3 & -22.3 & 1.22 & 1.13 & -0.09 \\
\hline Waters & 325 & 392 & 67 & 1145.0 & 1135.3 & -9.8 & 4.58 & 4.54 & -0.04 \\
\hline Rivers & 31 & 30 & -1 & 313.8 & 307.4 & -6.4 & 1.26 & 1.23 & -0.03 \\
\hline Bars (in rivers) & 10 & 16 & 6 & 33.2 & 3.5 & -29.7 & 0.13 & 0.01 & -0.12 \\
\hline Ditches and channels & 2 & 9 & 7 & 3.1 & 9.2 & 6.1 & 0.01 & 0.04 & 0.02 \\
\hline Lakes & 77 & 101 & 24 & 516.3 & 483.4 & -32.8 & 2.07 & 1.93 & -0.13 \\
\hline Ponds & 195 & 226 & 31 & 48.9 & 102.9 & 54.0 & 0.20 & 0.41 & 0.22 \\
\hline Sea (and lagoon) & 10 & 10 & 0 & 229.7 & 228.8 & -0.9 & 0.92 & 0.92 & 0.00 \\
\hline Agrarian fields & 1021 & 1430 & 409 & 15054.8 & 13819.6 & -1235.3 & 60.23 & 55.29 & -4.94 \\
\hline $\begin{array}{l}\text { Arable land. meadows and } \\
\text { pastures }\end{array}$ & 501 & 725 & 224 & 14832.3 & 13128.0 & -1704.2 & 59.34 & 52.52 & -6.82 \\
\hline Schrubby meadows & 0 & 309 & 309 & 0.0 & 519.2 & 519.2 & 0.00 & 2.08 & 2.08 \\
\hline Gardens & 520 & 396 & -124 & 222.6 & 172.3 & -50.3 & 0.89 & 0.69 & -0.20 \\
\hline Built-up territories & 305 & 756 & 451 & 308.5 & 690.9 & 382.4 & 1.23 & 2.76 & 1.53 \\
\hline Urban built-up & 21 & 43 & 22 & 46.5 & 114.2 & 67.7 & 0.19 & 0.46 & 0.27 \\
\hline Village built-up & 179 & 365 & 186 & 77.2 & 206.2 & 129.0 & 0.31 & 0.82 & 0.52 \\
\hline Industrial built-up & 25 & 88 & 63 & 86.4 & 112.2 & 25.7 & 0.35 & 0.45 & 0.10 \\
\hline Garden allotment built-up & 54 & 220 & 166 & 87.7 & 211.2 & 123.5 & 0.35 & 0.85 & 0.49 \\
\hline Country-houses built-up & 0 & 16 & 16 & 0.0 & 34.9 & 34.9 & 0.00 & 0.14 & 0.14 \\
\hline $\begin{array}{l}\text { Stadiums. hippodromes. } \\
\text { athletic fields }\end{array}$ & 6 & 7 & 1 & 3.1 & 4.0 & 1.0 & 0.01 & 0.02 & 0.00 \\
\hline Cemeteries & 20 & 17 & -3 & 7.6 & 8.2 & 0.6 & 0.03 & 0.03 & 0.00 \\
\hline Exploitable territories & 53 & 25 & -28 & 55.7 & 32.1 & -23.7 & 0.22 & 0.13 & -0.09 \\
\hline Quarries & 51 & 22 & -29 & 18.0 & 18.9 & 0.9 & 0.07 & 0.08 & 0.00 \\
\hline Peatbogs & 2 & 3 & 1 & 37.8 & 13.2 & -24.6 & 0.15 & 0.05 & -0.10 \\
\hline Infrastructure territories & 46 & 78 & 32 & 72.5 & 85.7 & 13.2 & 0.29 & $\mathbf{0 . 3 4}$ & 0.05 \\
\hline Infrastructure networks & 3 & 2 & -1 & 7.9 & 2.8 & -5.1 & 0.03 & 0.01 & -0.02 \\
\hline Streets and roads & 28 & 50 & 22 & 61.8 & 78.0 & 16.2 & 0.25 & 0.31 & 0.06 \\
\hline Embankments & 1 & 1 & 0 & 0.6 & 0.4 & -0.2 & 0.00 & 0.00 & 0.00 \\
\hline Docks & 10 & 19 & 9 & 1.1 & 1.2 & 0.1 & 0.00 & 0.00 & 0.00 \\
\hline Landfills & 4 & 6 & 2 & 1.2 & 3.3 & 2.1 & 0.00 & 0.01 & 0.01 \\
\hline Other categories & 37 & 38 & 1 & 157.7 & 116.6 & -41.1 & 0.63 & 0.47 & -0.16 \\
\hline Sands & 29 & 29 & 0 & 152.0 & 100.5 & -51.5 & 0.61 & 0.40 & -0.21 \\
\hline Stony land & 2 & 2 & 0 & 2.3 & 0.2 & -2.1 & 0.01 & 0.00 & -0.01 \\
\hline Heritage objects & 4 & 5 & 1 & 1.1 & 13.7 & 12.6 & 0.00 & 0.05 & 0.05 \\
\hline Foreign territory & 2 & 2 & 0 & 2.2 & 2.2 & 0.0 & 0.01 & 0.01 & 0.00 \\
\hline Total & 3127 & 4813 & 1686 & 24995.6 & 24995.6 & 0.0 & 100.00 & 100.00 & 0.00 \\
\hline
\end{tabular}




\section{Jankauskaitè M., Veteikis D. CHANGES OF LANDSCAPE SPATIAL STRUCTURE AS A RESULT OF TRANSFORMATION OF LAND-OWNERSHI}

TABLE 3 .

MAIN CHANGES (TRANSFORMATIONS OF LAND COVER CATEGORIES)

\begin{tabular}{|c|c|c|c|c|}
\hline Changes & $\begin{array}{l}\text { Number of } \\
\text { plots with } \\
\text { change }\end{array}$ & $\begin{array}{l}\% \text { from total } \\
\text { number }\end{array}$ & $\begin{array}{l}\text { Area (ha) of } \\
\text { plots with } \\
\text { changes }\end{array}$ & $\begin{array}{l}\% \text { from total } \\
\text { area }\end{array}$ \\
\hline \multicolumn{5}{|c|}{ Renaturalisation. land abandonment and conversion to forests. swamps and schrubs } \\
\hline Agrarian fields to forests and schrubs & 2673 & 30.7 & 1328.7 & 30.5 \\
\hline Agrarian fields to schrubby meadowss & 269 & 3.1 & 336.2 & 7.7 \\
\hline Agrarian fields to swamps & 133 & 1.5 & 63.2 & 1.5 \\
\hline Scrubs and young forests to forests & 247 & 2.8 & 256.6 & 5.9 \\
\hline Quarries and peatbogs to forests to forests and schrubs & 36 & 0.4 & 41.3 & 0.9 \\
\hline \multicolumn{5}{|l|}{ Conversion to agrarian land } \\
\hline Shrubs to agrarian fields & 208 & 2.4 & 30.5 & 0.7 \\
\hline Forests to agrarian fields & 1042 & 12.0 & 305.4 & 7.0 \\
\hline Swamps to agrarian fields & 43 & 0.5 & 66.6 & 1.5 \\
\hline Gardens to agrarian fields & 335 & 3.8 & 56.2 & 1.3 \\
\hline Build-up territories to agrarian fields & 143 & 1.6 & 42.7 & 1.0 \\
\hline \multicolumn{5}{|c|}{ Expansion of construction. infrastructure and recreational use } \\
\hline Agrarian fields to build-up territories & 717 & 8.2 & 397.8 & 9.1 \\
\hline Gardens to build-up territories & 224 & 2.6 & 42.8 & 1.0 \\
\hline Agrarian fields to gardens & 261 & 3.0 & 53.1 & 1.2 \\
\hline Agrarian fields to ponds & 166 & 1.9 & 55.8 & 1.3 \\
\hline \multicolumn{5}{|l|}{ Overgrowth of swamps and lakes } \\
\hline Swamps to forests and shrubs & 120 & 1.4 & 69.3 & 1.6 \\
\hline Lakes to forests. swamps and shrubs & 82 & 0.9 & 37.6 & 0.9 \\
\hline \multicolumn{5}{|l|}{ Other more important changes } \\
\hline Forests to young forests and shrubs & 257 & 3.0 & 351.7 & 8.1 \\
\hline Forests to forest cuttings & 127 & 1.5 & 240.2 & 5.5 \\
\hline Forests to shrubby meadows & 147 & 1.7 & 151.3 & 3.5 \\
\hline
\end{tabular}

Though increase of forested areas due to decrease of arable fields is observed also in other European countries $[7,8]$, it is usually associated with expansion of planted forests but not with forests which are naturally occupying an abandoned land. It is possible to state that the increase of land cover fragmentation was first of all predetermined by land reform which allowed formation of small landownership and the latter in turn lead to the land use fragmentation. Besides that, such processes as increase of built-up territories, expansion of recreational use in suburban territories, and forestation or spontaneous forestation of agrarian fields had and still have great influence on the growth of landscape fragmentation. Though presently the tendency of enlargement of farms can be noticed (first of all in fertile plains). This process is going on slowly and with difficulties because small landowners refuse to sell their land of agrarian use. Thus farmers are forced to rent the greater part of agrarian land. Manifestation of landscape re-naturalisation as a result of land abandonment and conversion to forests, swamps and shrubs, as well as, transformation of arable land to meadows and pastures are the main directions of land cover changes during the study period. According to some foreign authors [9, 10, 11, 12, 13], land abandonment and its spontaneous forestation is qualified as rather negative process, because of the loosing of land value from a cultural viewpoint and from ecological viewpoint, because of decrease of biodiversity during succession period. However, in Lithuania this process should be qualified positively, because it helps to restore the landscape stability in the sense of structure optimum after high landscape homogenisation experience in Soviet period.

Transformation of agrarian fields to forests and shrubs can be considered as the main axis of landscape structure conversion (it comprises more than $30 \%$ according to number of plots with changes and covered area). Though at the same time the conversion of forests and shrubs and other land use types to agrarian fields was also going on. but it had significantly lower scale and comprised only about $20 \%$ from total number of all plots with changes (the conversion of forests to agrarian fields was somewhat more distinct and made up $12 \%$ of the total number of plots with changes) (Table 3). Therefore in total. the part of natural land use types (forests. shrubs and swamps) increased by $3.7 \%$ during the study period. meanwhile the part of agrarian fields decreased by $4.9 \%$ respectively.

Quick expansion of construction, recreational use and infrastructure is another important landscape structure conversion which is opposite to the first one, because it 


\section{Jankauskaitė M., Veteikis D. CHANGES OF LANDSCAPE SPATIAL STRUCTURE AS A RESULT OF \\ TRANSFORMATION OF LAND-OWNERSHI}

goes towards technogenisation. It manifests mainly as the change of agrarian fields, suburban gardens to build-up territories resulting in the growth of the percentage of other land use types related to built-up territories (ponds, streets and roads). During the study period, the percentage of built-up territories increased more than twice (from 1.2 to $2.8 \%$ ).

It is possible to state that the processes of renaturalisation were predetermined by the poor state in the villages and agrarian sector due to prolonged reform of agriculture, also by EU support for forestation of unproductive land. Very quick expansion of built-up areas began after Lithuania joined EU and the growth of large cities and employment of recreation areas, especially near lakes, rivers and seashore. intensified.

Increase of forestation of swamps and decrease of the lake areas due to implementation of melioration in Soviet times is also noticeable during the study period. Especially intensive forest cuttings (which increased 7 times and which are observed in sandy plains) can also be mentioned among other changes.

\section{CONCLUSIONS}

All traces of past social economical reforms are reflected in the present mosaic of Lithuanian landscape. but they are especially distinct when Soviet economy changed to market economy. Observation of landscape changes during the period from the end of the Soviet times to the middle of the second decade of the Independence using cartographic material of detailed scale (1:10000) enabled to determine the following main tendencies of landscape structure changes.

Significant increase of land cover fragmentation (mosaic) due to growth of the shrubby and swampy territories both in the forested territories and in the agrarian fields. The average area of land use plot decreased almost twice.

More distinct manifestation of landscape renaturalisation through land abandonment and conversion to forests, swamps and shrubs, as well as through transformation of arable land to meadows and pastures. The conversion of forests, shrubs and other land use types to agrarian fields also takes place, but on markedly lower scale. Therefore in total the part of natural land use types (forests, shrubs and swamps) in land use structure increased by $3.7 \%$ during the study period, meanwhile the part of agrarian fields decreased by $4.9 \%$ respectively.

Acceleration of the conversion of landscape structure towards technogenisation through expansion of build-up territories, recreational use and expansion of road infrastructure. The part of built-up territories during the study period increased more than twice (from 1.2 to $2.8 \%$ ). The extent of forest cuttings increased 7 times.

\section{REFERENCES}

[1] Lietuvos gamtinè aplinka. būklè procesai. raida., Vilnius: Aplinkos apsaugos agentūra, 2008

[2] M. Jankauskaite, D. Veteikis D. (2011). "Experience analysis and sample distribution problems in local level landscape monitoring", in: Environment. Technology. Resources. Proceedings of the $8^{\text {th }}$ International Scientific Practical Conference. June 20-22. 2011, vol. I, Rezekne, 2011, pp. 31-37.

[3] D. Veteikis, S. Šabanovas, M. Jankauskaite, "Landscape structure changes on the coastal plain of Lithuania during 1998 - 2009", Baltica, vol. 24 (2), pp. 107-116, Dec. 2011.

[4] G. Ribokas, J. Milius, "Shifts of land use structure in north-east Lithuania after restoration of statehood", Annales Geographicae (Geographical Yearbook), vol. 40 (2), pp. 38-49, Sept. 2007.

[5] G. Ribokas, A. Zlatkute, "Land use dynamics in the Anykščiai district municipality (the case of Viešintos local administrative unit)", Annales Geographicae (Geographical Yearbook), vol. 42 (1-2), pp. 45-54, Jun. 2009.

[6] Lietuvos Respublikos kraštovaizdžio erdvinès struktūros ịvairovès ir jos tipu identifikavimo studija [Study of landscape spatial structure diversity and its types" identification of Lithuanian Republic]. 2006.2 Internet access: http://www.am.lt/VI/index.php\#r/1144

[7] P. Bibby, "Land use change in Britain", Land Use Policy, vol. 26, pp. 2-13, 2009.

[8] M. D. A. Rounsevell, D. S. Reay, "Land use and climate change in the UK", Land Use Policy, vol. 26, Supplement 1, pp. 160-169, 2009.

[9] E. Öckinger, A. K. Erikkson, H. G. Smith, "Effects of grassland abandoment, restoration and management on butterflies and vascular plants", Biological Conservation, vol. 133(3), pp. 291$300,2006$.

[10] R. Tarrega, L. Calvo, A. Taboada, S. Garcia-Tejero, E. Marcos, "Abandonment and management in Spanish dehesa systems: effects on soil features and plant species richness and composition", Forest ecology and management, vol. 257(2), pp. 731-738, 2009.

[11] [11]. J. Verhulst, A. Baldi, D. Kleijn, "Relationship between landuse intensity and species richness and abundance of birds in Hungary", Agriculture, Ecosystems \& Environment, vol. 104(3), pp. 465-473, 2004

[12] A. Palo, R. Aunap, U. Mander, "Predictive vegetation mapping based on soil and topographical data: A case study from Saare County, Estonia". Journal of Nature Conservation, vol. 13(2-3), pp. 197-211, 2005

[13] A. Kobler, T. Cunder, J. Pirnat, "Modelling spontaneous afforestation in Postojna area, Slovenia", Journal of Nature Conservation, vol. 13(2-3), pp. 127-135, 2005. 